\title{
AikUISSOSIAALITYÖN ASIAKKAIDEN TULEVAISUUTEEN SUHTAUTUMINEN JA TOIVEET
}

\author{
Eeva Ekqvist: YTM, yliopisto-opttaja, Tampereen yliopisto \\ Katja Kuusisto: YTT, dosentti, yliopistonlebtori, Tampereen yliopisto
}

eeva.ekqvist@tuni.fi; katja.n.kuusisto@tuni.fi

Janus vol. 28 (1) 2020, 42-59

\section{(J) Ja II U}

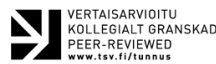

Tiivistelmä

Artikkelissa tarkastellaan 1) miten aikuissosiaalityön asiakkaat suhtautuvat tulevaisuuteensa, 2) riskitekijöitä,jotka ovat yhteydessä epävarmaan tulevaisuuteen suhtautumiseen sekä 3) mitä asiakkaat toivovat tulevaisuudeltaan. Aineisto muodostuu asiakastyytyväisyyskyselyn vastauksista $(N=272)$. Tulevaisuuteen suhtautuminen oli yhteydessä taustamuuttujiin, kuten ikään, sukupuoleen, työttömyyden ja asiakkuuden kestoon, vuorovaikutukseen työntekijän kanssa, työskentelysuhteen tavoitteellisuuteen sekä palveluodotuksiin vastaamiseen. Vastaajilla, joiden odotuksiin saatu palvelu ei vastannut, oli kuusinkertainen riski tulevaisuuteen epävarmasti suhtautumiseen verrattuna niihin, joiden odotuksiin palvelu oli vastannut. Myös työskentelyn tavoitteellisuuden laskiessa riski tulevaisuuteen epävarmasti suhtautumiselle kasvoi. Asiakkaiden tulevaisuuden toiveissa keskeisimmiksi nousevat työhön, koulutukseen ja taloudelliseen tilanteeseen liittyvät seikat.

\section{JOHDANTO}

Sosiaalipoliittiset päätökset ja sosiaalityön ajankohtaiset rakennemuutokset koskettavat sosiaalityön asiakkaita mitä suuremmassa määrin. Aikuissosiaalityössä merkittävä muutos tapahtui vuoden 2017 alussa, jolloin perustoimeentulotuki siirtyi Kelan hoidettavaksi. Siirto herätti ennalta huolta heikoimmassa asemassa olevien asiakkaiden pärjäämisestä ja avun saamisesta (Mäkinen 2014, 18-20) sekä asiakasryhmään kohdistuvista asenteista (Blomberg ym. 2016). Toisaalta sen toivottiin mahdollistavan suunnitelmallisen ja tavoitteellisen työskentelyn asiakkaiden kanssa (STM 2015, 24). Siirto ei sujunut täysin ongelmitta (ks. Kela 2017) ja se toi esiin sosiaalityön ja taloudellisen tuen yh- teenkietoutuneisuuden sekä erillisyyden. Pelkkä taloudellinen tuki ei välttämättä riitä asiakkaan elämäntilanteen paranemiseen, vaan lisäksi tarvitaan sosiaalityön palveluita ja psykososiaalista tukea (Kuusikko-työryhmä \& Borg 2011, 3-4). Psykososiaalisen tuen tarve ei myöskään välttämättä indikoi taloudellisen tuen tarvetta.

Sosiaalityötä kuvataan usein ongelmanratkaisutyöksi, jota toteutetaan suunnitelmallisesti tavoitteeseen pyrkien (Blomgren \& Kivipelto 2012, 37; Juhila 2008, 16-25; Rostila 2001). Keskeistä asiakaslähtöisessä tavoitteellisessa sosiaalityössä ja työskentelyn onnistumisessa on työntekijän usko asiakkaaseen ja asiakkaan mahdollisuus palveluiden saamiseen, vaikka taustalla olisi usei- 
takin epäonnistumisia (Jokinen 2014, 200-218). Resurssien puute on kuitenkin johtanut siihen, että paneutuvaa muutossosiaalityötä on voitu tarjota vain osalle asiakkaista (Kuusikko-työryhmä \& Borg 2011, 6-7). Aina muutos parempaan ei asetu edes tavoitteeksi, vaan työskentelyllä pyritään tilanteen säilyttämiseen ennallaan tai jopa tilanteen huononemisen estämiseen (Hokkanen 2012; Kivipelto ym. 2013, 43). Aikuissosiaalityössä tavoitteiden kenttä onkin hyvin moninainen. Työskentely voi kohdentua esimerkiksi elämänhallintaan, sosiaalisiin verkostoihin, työelämään ja koulutukseen, taloudelliseen tilanteeseen, terveyteen ja riippuvuuksiin (ks. esim. Kivipelto ym. 2013, 32).

Hyvä yhteistyösuhde mahdollistaa asiakkaan omien tavoitteiden esiin tuomisen. Osallistuminen suunnitelmalliseen, asiakaslähtöiseen prosessiin nostaa esiin asiakkaan tietoisuutta siitä, että hän voi itse vaikuttaa asioidensa kehitykseen ja saa siihen ammatillista tukea (Rantasalmi 2008, 16). Toimivalla vuorovaikutuksella asiakkaan ja työntekijän välillä, tavoitteellisella työskentelyotteella ja asiakkaan palveluodotuksiin vastaamisella on todettu olevan yhteyttä aikuissosiaalityön asiakkaiden kokemukseen elämäntilanteensa paranemisesta (Kuusisto \& Ekqvist 2016). Sosiaalityöntekijöiden palveluohjauksellista osaamista ja asiakasta kuulevaa työotetta tulisikin vahvistaa unohtamatta luottamuksellisuuden merkitystä hyvän asiakassuhteen toteutumiselle (Blomgren \& Kivipelto 2012, 40; Nummela 2011, 141-143).

Suunnitelmallisella työskentelyllä asiakasta autetaan löytämään omat tavoitteensa ja tunnistamaan voimava- ransa sekä näkemään tulevaisuutensa positiivisessa valossa (Hepworth ym. 2010, 34-36; Koehn \& Cutcliffe 2012, 85-92; Rantasalmi 2008, 23). Tällöin työskentelymenetelmiksi asettuvat muun muassa asiakkaan voimavarojen kartoittaminen, erilaisten vaihtoehtojen ja mahdollisuuksien etsiminen sekä asiakkaan motivointi muutokseen (Juhila 2008, 16-25). Aikuissosiaalityötä toteutetaan kuitenkin monelta taholta tulevan ristipaineen alla.Vaikka käytännön sosiaalityössä pyritään tavoitteiden luontiin kunkin asiakkaan yksilöllinen elämäntilanne huomioon ottaen, työskentelyä ohjaavat vahvasti yhteiskunnalliset ja organisatoriset tehokkuuden ja vaikuttavuuden vaateet (Juhila 2009) sekä vallalla olevat arvot ja politiikat (Kjørstad 2005). Tästä syystä on erityisen tärkeää tunnistaa ja antaa tilaa asiakkaiden näkemyksille ja pyrkimyksille oman tulevaisuutensa suhteen.

Artikkelissa tarkastelemme 1) miten aikuissosiaalityön asiakkaat suhtautuvat tulevaisuuteensa ja etsimme 2) riskitekijöitä, jotka ovat yhteydessä epävarmaan tulevaisuuteen suhtautumiseen. Lisäksi tutkimme 3) mitä aikuissosiaalityön asiakkaat toivovat tulevaisuudeltaan. Tulevaisuuteen suhtautumista ja epävarmuuden riskitekijöitä tutkimme kvantitatiivisin menetelmin vuonna 2014 kerättyä kyselylomakeaineistoa $(N=272)$ hyödyntäen. Tulevaisuuden toiveita tarkastelemme sisällön erittelyn ja kvantifioinnin keinoin kyselomakkeen tulevaisuutta koskevan avokysymyksen vastauksista $(n=204)$. Näin tavoittelemme moniulotteista kuvaa aikuissosiaalityön asiakkaiden suhtautumisesta tulevaisuuteen sekä siihen kohdentuvista toiveista. 
TulevaisuUteen SUhtautuminen JA TULEVAISUUDEN TOIVEET

AIKAISEMMASSA TUTKIMUKSESSA

Yksilön päätökset ja toiminta nykyhetkessä ovat yhteydessä siihen, millaisena hän näkee tulevaisuutensa. Tulevaisuuteen pyritään joko vaikuttamaan tai sopeutumaan nykyhetken valinnoilla. (Bell 2003/1997, 82.) Henkilön näkemykset omista kyvyistään ja mahdollisuuksistaan sekä aikaisempi elämänkokemus vaikuttavat käsitykseen tulevaisuudesta. Tulevaisuutta koskevilla toiveilla, peloilla ja uhilla sekä yhteiskunnassa vallalla olevilla arvoilla on tässä roolinsa. (Rubin \& Linturi 2001.)

Tasapainoinen suhtautuminen menneisyyteen ja tulevaisuuteen heijastuu onnellisuuteen, elämäntyytyväisyyteen sekä hyvään itsetuntoon (Webster \& Ma 2013; Webster 2011). Tulevaisuuden ajattelu ja suunnittelu näyttävät suojaavan toivottomuudelta, masennusoireilta (Chin \& Holden 2013) sekä itsetuhoisuudelta (Hirsch ym. 2006). Muun muassa heikko taloudellinen tilanne, työttömyys, terveydelliset tai ympäristöön liittyvät huolet on aikaisemmassa tutkimuksessa määritelty toivottomuutta lisääviksi tekijöiksi (esim. Haatainen 2004, 55-60; Pulkkinen \& Polet 2010, 85-90). Toivottomuutta sen sijaan on havaittu vähentävän taloudellisen turvallisuuden tunne, terveys, hyvät ihmissuhteet, positiiviset muutokset elinolosuhteissa ja kokemus siitä, että voi itse vaikuttaa tulevaisuuteensa (esim. Haatainen 2004, 55-60; Kärnä 2008, 188-194).

Aikuissosiaalityössä panostetaan usein erityisesti nuorten, 18-30 -vuotiaiden asiakkaiden tulevaisuuden suun- nitteluun, joka asettuu myös nuorten omaksi toiveeksi asiakkuutensa suhteen (Saikkonen ym. 2015, 36). Nuorten tulevaisuutta on tutkittu etenkin koulutuksen ja työelämään siirtymisen näkökulmasta (esim. Aapola-Kari \& Wrede-Jäntti 2017; Nurmi \& Salmela-Aro 2002; Rubin \& Linturi 2001; Shulman ym. 2015). Nuorilla tulevaisuuden tavoitteet kohdistuvat erityisesti koulutukseen, mutta iän myötä ne vaihtuvat työelämään liittyviin toiveisiin. Myös perheeseen ja parisuhteeseen liittyvät toiveet yleistyvät iän karttuessa. (Dietrich ym. 2013.) Nuorisobarometrin kartoituksen mukaan suomalaisnuorista liki yhdeksän kymmenestä suhtautuu tulevaisuuteensa optimistisesti tyttöjen ollessa hieman poikia luottavaisempia (Myllyniemi 2017, 36).

Aikuisväestöllä tulevaisuuteen optimistisesti suhtautumisen on havaittu olevan yhtä yleistä kuin nuorilla. Kokemus mahdollisuudesta vaikuttaa elämäntilanteeseensa sekä selvät tulevaisuuden suunnitelmat ovat yhteydessä optimismiin. Sen sijaan on todettu, että iän myötä sairauteen ja taloudelliseen tilanteeseen liittyvät pelot lisääntyvät. (Kärnä 2008, 188-194; Pulkkinen ym. 2003, 84; Pulkkinen \& Polet 2010, 8590; ks. myös Barnett 2014). Tutkimuksessa suomalaisten aikuisten arjesta toiveiksi nousivat hyvä terveys, pitkä ikä, taloudellinen turvallisuus sekä yleinen hyvinvointi. Vastaajat toivoivat arkeensa jatkuvuutta ja pysyvyyttä; välttymistä ikäviltä elämänmuutoksilta. (Jokinen 2005, 160-161.) Aikuissosiaalityön asiakkaiden asiakkuudelleen asettamat tavoitteet myötäilevät näitä toiveita, joskin taloudelliseen tilanteeseen ja työllistymiseen liittyvät tavoitteet nou- 
sevat keskeisiksi työskentelyn kohteiksi (Kivipelto ym. 2013).

\section{TutKimukSEN TOTEUTTAMINEN}

\section{Tutkimusasetelma}

Tutkimus toteutettiin kyselytutkimuksena suuren suomalaisen kaupungin aikuissosiaalityön ja toimeentulotuen yksikössä osana SOS II-hanketta, joka kuului STM:n KASTE-kehittämisohjelmaan. Tutkimuslupa saatiin tammikuussa 2014 ja aineistonkeruu toteutettiin poikittaistutkimuksena helmi-maaliskuussa 2014. Aineisto on valikoimaton kokonaisotos kyseisenä ajankohtana aikuissosiaalityössä ja toimeentulotukiyksikössä asioineita asiakkaita. Asiakkaat antoivat suostumuksensa tutkimukseen täyttämällä puolistrukturoidun kyselylomakkeen.

Kyselyyn oli mahdollista vastata joko paperilomakkeella tai sähköisesti. Kyselyä jaettiin sekä työntekijän tapaamisella $(n=387)$ että toimeentulotukipäätöksen liitteenä $(n=1000)$. Vastaajia oli kaikkiaan 272, joten vain 20 prosenttia (27\% kasvokkain asioivista; $16 \%$ kirjallisesti asioivista) kyselyn saaneista vastasi siihen. Ennakolta matalaksi arvioitua vastausprosenttia pyrittiin nostamaan tarjoamalla myös sähköinen vastaamismuoto. Sähköistä vastaamisvaihtoehtoa käytti kuitenkin vain 20 henkilöä. Otoksen pienuuteen on voinut johtaa käytäntö, jossa suurin osa kyselyistä toimitettiin asiakkaalle kirjallisen toimeentulotukipäätöksen yhteydessä. Tämä voi vaikuttaa asiakkaan vastaushalukkuuteen (vrt. Kemppainen ym. 2010,79), kuten myös tutkimuksen kohderyhmä,joka saattaa olla hankalas- ti tavoitettava. Tutkimuksen yleistettävyyttä arvioitaessa on huomioitava aineistonkeruun kohdentuminen yhteen kaupunkiin rajallisena ajankohtana sekä kadon suuruus.

Tutkimuksessa käytetyt munttujat ja menetelmät

Tutkimuksessa käytetty asiakastyytyväisyyteen kohdentuva puolistrukturoitu kyselylomake mahdollistaa sekä tilastollisen tarkastelun että avokysymysten kvantifioivan analyysin. Tulevaisuuteen suhtautumista tarkasteltiin tilastollisin menetelmin. Vastemuuttujana oli aikuissosiaalityön asiakkaiden luottamus tulevaisuuteen (suhtaudun tulevaisuuteeni luottavaisin mielin; tulevaisuus tuntuu epävarmalta). Demografisina taustamuuttujina käytettiin asiakkaan ikää ja työtilannetta. Lisäksi taustamuuttujana käytettiin nykyisen asiakkuuden kestoa.

Palvelun laatua tarkasteltiin asiakkaiden kokemuksena vuorovaikutuksesta työntekijän kanssa, palveluodotusten täyttymisenä ja työskentelyn tavoitteellisuutena. Vuorovaikutuskokemusta tutkittaessa vastaajaa pyydettiin arvioimaan 5-portaisella Osgoodin asteikolla kuinka rauhallista tai kiireistä, asiantuntevaa tai asiantuntematonta, empaattista tai ymmärtämätöntä, kunnioittavaa tai epäkunnioittavaa, läsnä olevaa tai etäistä sekä joustavaa tai joustamatonta vuorovaikutus asiakaskohtaamisessa oli ollut. Muuttujista muodostettiin työntekijän ja asiakkaan välistä vuorovaikutusta kuvaava summamuuttuja. Sisällöllisen arvioinnin lisäksi Cronbachin alfa -testillä todettiin, että osamuuttujat mittaavat erinomaisesti samaa asiaa $(\alpha=, 934$; $n=200)$. Pienempää vastaajajoukkoa summamuuttujien osalta selittää se, että 
summamuuttuja vaatii vastauksen jokaiseen osamuuttujaan.

Palveluodotusten kohdalla asiakkailta kysyttiin neliluokkaisella muuttujalla, kuinka palvelu on vastannut heidän odotuksiaan (erittäin hyvin; hyvin; huonosti; erittäin huonosti). Luokat yhdistettiin kaksiluokkaiseksi muuttujaksi, jonka avulla voitiin tarkastella, onko palvelu vastannut heidän odotuksiaan hyvin vai huonosti.

Työskentelyn tavoitteellisuutta kuvaava summamuuttuja $(\alpha=, 954 ; n=153)$ muodostettiin 5-portaisista Likert-asteikollisista väittämistä, joilla selvitettiin, saiko asiakas työntekijältä tietoa palveluista, jotka voisivat auttaa häntä, oliko työntekijällä samanlainen käsitys asiakkaan avuntarpeesta kuin hänellä itsellään, tiesikö asiakas, miten hänen asiansa etenevät tapaamisen jälkeen sekä kuinka hyödyllinen laadittu palvelusuunnitelma oli. Summamuuttuja kuvaa tavoitteellista työskentelyä konkreettisella tasolla.

Elämäntilanteen muutosta kuvaava muuttuja jakautui kolmeen luokkaan: elämäntilanne on parantunut, pysynyt samana tai heikentynyt sosiaalitoimen asiakkuuden myötä.

Analysointi aloitettiin muuttujien jakaumia kuvailevilla tarkasteluilla ja sitä jatkettiin ristiintaulukoinnein. Lopuksi selvittääksemme syitä tulevaisuuteen epävarmasti suhtautumiselle sekä tarkastellaksemme eri tekijöiden vaikutusten suuruutta käytimme analyysimenetelmänä binäärilogistista regressioanalyysïa (LRA). Tarkoituksena oli muodostaa sekä vastaajien taustatiedoista että asiakkuuteen liittyvistä muuttujista malli ennustamaan tule- vaisuuteen epävarmasti suhtautumista. Logistisen regressioanalyysin tuloksia esitetään usein riskinä jonkin asian tapahtumiselle (Jokivuori \& Hietala 2007, 70; vrt. Rita ym. 2008).

Toteutimme LRA:n pakotetusti, eli valitsimme malliin lisättävät muuttujat kahdenvälisten tarkastelujen ja merkitsevyystestausten pohjalta. Sisällöllisen arvioinnin lisäksi mallin muuttujien valinnassa huomioitiin kolineaarisuustestin tulokset. (Ks. Jokivuori \& Hietala 2007, 56-77.) Näiden perusteella tulevaisuuteen epävarmasti suhtautumista selittäviksi taustamuuttujiksi valittiin sukupuoli ja työtilanne.Asiakkuutta kuvaavista muuttujista malliin valittiin asiakkuuden kesto, työskentelysuhteen tavoitteellisuus, elämäntilanteen muutos asiakkuuden myötä sekä palveluodotuksiin vastaaminen. Tavoitteellisuus ja vuorovaikutus korreloivat vahvasti keskenään $\left(\mathrm{r}_{\mathrm{s}}=, 781 ; \mathrm{p}<, 001\right)$, mikä ohjasi toisen selittävän muuttujan jättämiseen pois analyysistä. Tulkitsimme tulevaisuuteen suhtautumista nimenomaan tavoitteellisuuden ja tavoitteiden asettamisen kautta, joten analyysissä säilytettiin työskentelyn tavoitteellisuus. Tavoitteellisuus korreloi myös elämäntilanteen muutoksen kanssa, mutta kolineaarisuustestissä muuttujien välinen yhteys jäi viiterajojen sisälle.

Tulevaisuuteen suhtautumisen lisäksi tutkimme aikuissosiaalityön asiakkaiden tulevaisuuteen kohdentuvia toiveita pyrkimyksenämme tuottaa moniulotteinen kuva tutkittavasta ilmiöstä (ks. Greene ym. 2010). Tulevaisuuden toiveita tarkasteltiin vastauksista avokysymykseen: Minkälaisen toivoisit oman tilanteesi olevan vuoden kuluttua? Tulevaisuutta kuvaili yhteensä 204 vastaajaa, 
joilla toiveiden määrä vaihteli yhdestä viiteen per vastaaja. Vastaukset vaihtelivat pituudeltaan yhdestä sanasta muutamaan virkkeeseen. Yhteensä vastauksista muodostui kahdeksan tekstisivua. Vastauksista tehtiin sisällön erittelyä niiden ollessa jo valmiiksi muodossa, jossa niistä saattoi etsiä samanlaisuuksia ja eroavaisuuksia. Lisäksi niitä voitiin luokitella kokoavien käsitteiden alle. (Tuomi \& Sarajärvi 2009, 106-109.) Tyypillinen vastaus oli listamuotoinen, kuten "Toivon mieheni olevan töissä, taloudellinen tilanne tasaantunut ja muиt (terveydelliset) asiat hallinnassa”.

\section{Tulokset}

\section{Vastaajien taustatietoja}

Taulukosta 1 on nähtävissä vastaajien taustatietoja. Vastaajissa oli hiukan enemmän naisia kuin miehiä. Ikäryhmänä alle 30-vuotiaat muodostivat enemmistön. Valtaosalla oli toisen asteen koulutus. Pääosa vastaajista asui yksin. Suurin osa vastaajista oli työttömänä ja heistä suurimmalla osalla työttömyys oli kestänyt alle vuoden. Seuraavaksi suurin vastaajaryhmä oli

Taulukko 1. Vastaajien $(N=272)$ taustatietoja

\begin{tabular}{|c|c|c|}
\hline & $n$ & $\%$ \\
\hline \multicolumn{3}{|l|}{ Sukupuoli $(n=271)$} \\
\hline nainen & 140 & 51,7 \\
\hline mies & 131 & 48,3 \\
\hline \multicolumn{3}{|l|}{ Ikäluokka $(n=269)$} \\
\hline alle 30-vuotiaat & 108 & 40,1 \\
\hline 30-39-vuotiaat & 52 & 19,3 \\
\hline 40-49-vuotiaat & 47 & 17,5 \\
\hline 50 -vuotiaat ja vanhemmat & 62 & 23,0 \\
\hline \multicolumn{3}{|l|}{ Koulutustausta $(n=271)$} \\
\hline perusasteen koulutus & 84 & 31,0 \\
\hline toisen asteen koulutus (lukio tai ammatillinen koulutus) & 149 & 55,0 \\
\hline korkea-asteen koulutus (ammattikorkeakoulu, yliopisto) & 38 & 14,0 \\
\hline \multicolumn{3}{|l|}{ Asumismuoto $(n=271)$} \\
\hline yksin & 192 & 70,8 \\
\hline puolison kanssa & 19 & 7,0 \\
\hline lapsen/lasten kanssa & 23 & 8,5 \\
\hline puolison ja lapsen/lasten kanssa & 18 & 6,6 \\
\hline muu asumismuoto & 19 & 7,0 \\
\hline \multicolumn{3}{|l|}{ Työtilanne $(n=267)$} \\
\hline työssä tai eläkkeellä & 27 & 10,1 \\
\hline opiskelijana & 40 & 15,0 \\
\hline työttömänä & 155 & 58,0 \\
\hline jossakin muussa elämäntilanteessa & 45 & 16,9 \\
\hline \multicolumn{3}{|l|}{ Työttömyyden kesto ( $n=152$ ) } \\
\hline alle vuoden & 62 & 40,8 \\
\hline $1-2$ vuotta & 38 & 25,0 \\
\hline yli 2 vuotta & 52 & 34,2 \\
\hline
\end{tabular}


opiskelijat; ansiotyössä käyvien osuus oli selvästi pienempi. Demografisten tietojen osalta tähän tutkimukseen osallistuneet vastasivat hyvin tuolloista valtakunnallista kuvaa toimeentulotuen saajista (Toimeentulotuki 2014, 2-3).

Vastaajien aikuissosiaalityön asiakkuutta koskevat tiedot löytyvät taulukosta 2. Suurin osa vastaajista asioi pääasiassa kirjallisesti. Vastaajista viidennes oli ensikertaa asioivia, pisimpään asioinut vastaaja ilmoitti nykyisen asiakkuuden kestoksi 16,5 vuotta. Palvelu onnistui vastaamaan asiakkaan odotuksiin noin kolmella neljästä vastaajasta.Viidenneksellä asiakkaista vuorovaikutuskokemus työntekijän kanssa oli negatiivinen eikä työskentelyä koettu tavoitteelliseksi ${ }^{1}$. Yli puolet vastaajista koki elämäntilanteensa parantuneen asiakkuuden myötä (ks. Kuusisto \& Ekqvist 2016).

Taulukko 2. Vastaajien $(N=272)$ asiakkuutta koskevia tietoja

\begin{tabular}{|c|c|c|}
\hline & $n$ & $\%$ \\
\hline \multicolumn{3}{|c|}{ Pääasiallinen palvelumuoto aikuissosiaalityössä ( $n=263)$} \\
\hline kasvokkainen asiointi & 103 & 39,2 \\
\hline asioi kirjallisesti & 160 & 60,8 \\
\hline \multicolumn{3}{|l|}{ Ensikertaa asioiva $(n=270)$} \\
\hline kyllä & 57 & 21,1 \\
\hline ei & 213 & 78,9 \\
\hline \multicolumn{3}{|l|}{ Nykyisen asiakkuuden kesto $(n=250)$} \\
\hline $0-1 \mathrm{kk}$ & 53 & 21,2 \\
\hline $2-6 \mathrm{kk}$ & 47 & 18,8 \\
\hline $7-12 \mathrm{kk}$ & 52 & 20,8 \\
\hline $13-24 \mathrm{kk}$ & 40 & 16,0 \\
\hline $25 \mathrm{kk}$ ja pidempään & 58 & 23,2 \\
\hline \multicolumn{3}{|l|}{ Palvelu vastannut odotuksia $(n=256)$} \\
\hline hyvin & 196 & 76,6 \\
\hline huonosti & 60 & 23,4 \\
\hline \multicolumn{3}{|l|}{ Kokemus vuorovaikutuksesta $(n=200)$} \\
\hline positiivinen & 123 & 61,5 \\
\hline neutraali & 43 & 21,5 \\
\hline negatiivinen & 34 & 17,0 \\
\hline \multicolumn{3}{|l|}{ Työskentelyn tavoitteellisuus ( $n=153)$} \\
\hline tavoitteellista & 92 & 60,1 \\
\hline neutraalia & 31 & 20,3 \\
\hline ei tavoitteellista & 30 & 19,6 \\
\hline \multicolumn{3}{|c|}{ Koettu elämäntilanteen muutos asiakkuuden myötä ( $n=254)$} \\
\hline parantunut & 140 & 55,1 \\
\hline pysynyt samana & 82 & 32,3 \\
\hline heikentynyt & 32 & 12,6 \\
\hline
\end{tabular}


Tulevaisuuteen suhtautuminen taustamunt- kun taas loput $(n=98)$ olivat epävarmotujien ja asiakkuutta koskevien tietojen va- ja tulevaisuutensa suhteen. Tarkemmat lossa kahdenvälisten tarkastelujen tulokset tulevaisuuteen suhtautumisesta ja vas-

Vastaajista 62 prosenttia $(n=159)$ suhtaajien tausta- ja asiakkuutta koskevista tautui tulevaisuuteensa luottavaisesti, tiedoista on esitelty taulukossa 3.

Taulukko 3. Tulevaisuuteen suhtautuminen ja analyyseissä käytetyt muuttujat ristiintaulukoituna

\begin{tabular}{|c|c|c|c|c|c|}
\hline & & Tulevaisuute & Ihtautuminen & & \\
\hline Selittäv & uuttuja & Luottavaisesti & Epävarmasti & Pearsonin & \\
\hline Sukupuoli $(n=256)$ & nainen & 69,1 & 30,9 & 6,722 &, 010 \\
\hline & mies & 53,3 & 46,7 & & \\
\hline Koulutus ( $n=256)$ & perusasteen koulutus & 66,3 & 33,8 & 2,38 & ,304 \\
\hline & toisen asteen koulutus (lukio & 61,9 & 38,1 & & \\
\hline & $\begin{array}{l}\text { korkea-asteen koulutus } \\
\text { (ammattikorkeakoulu, } \\
\text { yliopisto) }\end{array}$ & 51,4 & 48,6 & & \\
\hline Asuminen $(n=256)$ & yksin & 58,6 & 41,4 & 9,081 &, 059 \\
\hline & puolison kanssa & 55,6 & 44,4 & & \\
\hline & lapsen/lasten kanssa & 82,6 & 17,4 & & \\
\hline & $\begin{array}{l}\text { puolison ja lapsen/lasten } \\
\text { kanssa }\end{array}$ & 56,3 & 43,8 & & \\
\hline & muu asumismuoto & 83,3 & 16,7 & & \\
\hline Äidinkieli ( $n=253$ ) & suomi/ruotsi & 61,3 & 38,7 & 0,205 &, 650 \\
\hline & jokin muu & 66,7 & 33,3 & & \\
\hline Ikä $(n=255)$ & alle 30 -vuotiaat & 74,0 & 26,0 & 13,044 &, 005 \\
\hline & 30-39 -vuotiaat & 51,1 & 48,9 & & \\
\hline & $40-49$-vuotiaat & 62,8 & 37,2 & & \\
\hline & $\begin{array}{l}50 \text { vuotta täyttäneet ja } \\
\text { vanhemmat }\end{array}$ & 49,2 & 50,8 & & \\
\hline Asiakkuuden kesto $(n=238)$ & $0-6 \mathrm{kk}$ & 69,1 & 30,9 & 11,375 &, 023 \\
\hline & $7-12 \mathrm{kk}$ & 69,4 & 30,6 & & \\
\hline & 1-2 vuotta & 57,9 & 42,1 & & \\
\hline & $2-4$ vuotta & 41,7 & 58,3 & & \\
\hline & yli 4 vuotta & 45,5 & 54,5 & & \\
\hline Työtilanne ( $n=252)$ & työssä tai eläkkeellä & 83,3 & 16,7 & 9,975 & 019 \\
\hline & opiskelijana & 74,4 & 25,6 & & \\
\hline & työttömänä & 56,7 & 43,3 & & \\
\hline & jossakin muussa & 54,5 & 45,5 & & \\
\hline & elämäntilanteessa & & & & \\
\hline Työttömyyden kesto $(n=142)$ & alle vuoden & 70,7 & 29,3 & 10,269 &, 006 \\
\hline & $1-2$ vuotta & 48,5 & 51,5 & & \\
\hline & yli 2 vuotta & 41,2 & 58,8 & & \\
\hline Palvelu vastannut odotuksia & hyvin & 72,9 & 27,1 & 36,001 & $<, 001$ \\
\hline$(n=252)$ & huonosti & 30,0 & 70,0 & & \\
\hline Elämäntilanteen muutos & parantunut & 73,9 & 26,1 & 24,641 & $<, 001$ \\
\hline asiakkuuden myötä & pysynyt samana & 54,3 & 45,7 & & \\
\hline$(n=250)$ & heikentynyt & 29,0 & 71,0 & & \\
\hline Kokemus vuorovaikutuksesta & positiivinen & 75,7 & 24,3 & 24,535 & $<, 001$ \\
\hline$(n=190)$ & neutraali & 41,9 & 58,1 & & \\
\hline & negatiivinen & 37,5 & 62,5 & & \\
\hline Työskentelyn tavoitteellisuus & tavoitteellista & 78,4 & 21,6 & 32,958 & $<, 001$ \\
\hline$(n=148)$ & neutraalia & 36,7 & 63,3 & & \\
\hline & ei tavoitteellista & 26,7 & 73,3 & & \\
\hline Yhteensä $(n=256)$ & & 61,9 & 38,1 & & \\
\hline
\end{tabular}


Naiset suhtautuivat tulevaisuuteensa useammin luottavaisesti kuin miehet. Alle 30-vuotiailla luottavaisuus oli yleisempää kuin vanhemmissa ikäryhmissä. Myös työssäkäyvillä, eläkeläisillä ja opiskelijoilla tulevaisuuteen luottavaisesti suhtautuminen oli työttömänä tai muussa elämäntilanteessa olevia yleisempää. Alle vuoden kestänyt työttömyys sekä sosiaalitoimen asiakkuus olivat yhteydessä tulevaisuuteen luottavaisesti suhtautumiseen. Ristiintaulukoinnissa vastaajan koulutustaustalla, asumismuodolla ja äidinkielellä ei ollut tilastollisesti merkitsevää yhteyttä tulevaisuuteen suhtautumiseen.

Jopa 73 prosenttia niistä, jotka kuvasivat palvelun vastanneen odotuksia hyvin, suhtautui tulevaisuuteen luottavaisesti. Asiakkaat, jotka kokivat elämäntilanteensa parantuneen sosiaalitoimessa asioinnin myötä, suhtautuivat tulevaisuuteensa useammin luottavaisesti kuin vastaajat, joilla oli kokemus elämäntilanteen heikkenemisestä. Luottavaisesti tulevaisuuteen suhtautuminen oli myös yleisempää niillä vastaajilla, joilla oli ollut positiivinen vuorovaikutuskokemus työntekijän kanssa. Negatiivinen vuorovaikutuskokemus oli sen sijaan yhteydessä epävarmuuteen tulevaisuuden suhteen. Jopa yli kolme neljästä vastaajasta, joiden työskentelysuhdetta työntekijän kanssa voitiin kuvailla tavoitteelliseksi, kertoi suhtautuvansa tulevaisuuteen luottavaisin mielin. Tilanne oli päinvastainen niiden kohdalla, joiden asiakkuutta ei voitu kuvata tavoitteelliseksi.

Riskit tulevaisunteen epävarmasti suhtautumiselle

Tutkimuksen tavoitteena oli saada tietoa myös siitä, mitkä tekijät vaikuttavat tulevaisuuteen epävarmasti suhtautumiseen. Näitä riskitekijöitä kartoitettiin kahdenvälisten tarkastelujen lisäksi LRA:n avulla. Taulukosta 4 on nähtävissä tulevaisuuteen epävarmasti suhtautumista ennustavat taustatekijät. Muodostettu

Taulukko 4. Binäärilogistinen regressioanalyysi tulevaisuuteen epävarmasti suhtautumisesta

\begin{tabular}{|c|c|c|c|c|c|}
\hline \multirow{2}{*}{\multicolumn{2}{|c|}{$\begin{array}{l}\text { Tulevaisuuteen epävarmasti suhtautumista } \\
\text { selittävät tekijät }\end{array}$}} & \multirow[b]{2}{*}{ p-arvo } & \multirow{3}{*}{ Vetosuhde } & \multicolumn{2}{|c|}{$95 \%$ luottamusväli } \\
\hline & & & & Alaraja & Yläraja \\
\hline \multirow[t]{2}{*}{ Sukupuoli } & nainen & & & & \\
\hline & mies &, 039 & 2,787 & 1,052 & 7,381 \\
\hline \multirow[t]{4}{*}{ Työtilanne } & työssä tai eläkkeellä & ,408 & 1 & & \\
\hline & opiskelijana & 619 & 1,724 & 0,202 & 14,739 \\
\hline & työttömänä &, 859 & 1,17 & 0,207 & 6,626 \\
\hline & $\begin{array}{l}\text { jossakin muussa } \\
\text { elämäntilanteessa }\end{array}$ &, 261 & 2,861 & 0,457 & 17,89 \\
\hline Asiakkuuden kesto & &, 145 & 1,014 & 0,995 & 1,033 \\
\hline \multirow[t]{2}{*}{ Palvelu vastannut odotuksia } & hyvin & & 1 & & \\
\hline & huonosti &, 018 & 6,352 & 1,373 & 29,377 \\
\hline \multirow[t]{3}{*}{ Elämäntilanteen muutos } & parantunut & 695 & 1 & & \\
\hline & pysynyt samana & 637 & 1,316 & 0,42 & 4,125 \\
\hline & huonontunut & ,405 & 2,227 & 0,338 & 14,692 \\
\hline Työskentelyn tavoitteellisuus & &, 028 &, 520 &, 290 & ,932 \\
\hline
\end{tabular}


malli selitti tulevaisuuteen suhtautumisen vaihtelusta 36-49 prosenttia $\left(R^{2}=0,364-\right.$ $0,491)$. Aineiston koosta johtuen luottamusvälit muodostuivat laajoiksi, mistä syystä tuloksia voidaan pitää suuntaa antavina.

Sukupuoli nousi tilastollisesti merkitseväksi selittäjäksi; miehillä riski tulevaisuuteen epävarmasti suhtautumiseen on melkein kolminkertainen verrattuna naisiin. Mikäli palveluodotukset olivat täyttyneet huonosti, riski tulevaisuuteen epävarmasti suhtautumiseen oli yli kuusinkertainen verrattuna niihin vastaajiin, joiden odotuksiin palvelu oli vastannut. Myös työskentelyn tavoitteellisuuden laskiessa riski epävarmuuteen kasvoi liki kaksinkertaiseksi $(1 / 0,520=1,923)$. Vastaajien työtilanne, asiakkuuden kesto ja koettu elämäntilanteen muutos eivät ennustaneet epävarmaa suhtautumista tulevaisuuteen.

\section{Tulevaisuuden toiveet}

Aikuissosiaalityön asiakkaiden tulevaisuuden toiveita tarkasteltiin vastauksista avokysymykseen: Millaisen toivoisit tilanteesi olevan vuoden kuluttua? Taulukosta 5 on nähtävillä vastaajien $(n=204)$ tulevaisuuden toiveita $(n=378)$ yhdeksän teeman mukaisesti luokiteltuna.
Työ osoittautui yleisimmäksi toiveeksi pitäen sisällään erilaiset työsuhdemuodot sekä kuntouttavan työtoiminnan tai työkokeilun. Osalla työ oli vastaajan ainoa toive $(n=24)$, osalla taas esimerkiksi vaihtoehto opiskelulle tai sen rinnalle $(n=45)$. Vastaajista 37 kirjoitti toivovansa työtä, koska koki sen parantavan taloudellista tilannetta. Opintoihin liittyviä toiveita esitti 65 vastaajaa.

Vastaajista lähes kolmannes esitti taloudelliseen tilanteeseen liittyviä toiveita, mutta vain 14 vastaajalle se oli ainoa toive. Taloudelliseen tilanteeseen liittyviä toiveita esiintyi muiden toiveiden rinnalla. Pieni osa vastaajista toivoi lottovoittoa tai miljoonatuloja $(n=5)$, mutta muutoin taloudellisen tilanteen kohenemisella tavoiteltiin perustarpeiden tyydyttämistä.

Vastaajista 36 esitti toiveenaan sen, ettei olisi vuoden kuluttua enää sosiaalitoimen asiakkaana tai ei tarvitsisi toimeentulotukea. Pääasiallinen keino, jolla vastausten perusteella asiakkuudesta irtautumiseen pyritään, oli työn saaminen. Kahdeksalla vastaajalla asiakkuuden loppuminen oli ainoa toive. Vain pieni osa vastaajista $(n=7)$ toivoi asiakkuutensa jatkuvan ja saavansa am-

Taulukko 5. Vastaajien $(n=204)$ tulevaisuuden toiveet teemoiteltuna

\begin{tabular}{lcc}
\hline \multicolumn{1}{c}{ Toive } & $\mathrm{n}$ & $\%$ \\
\hline Työ & 120 & 31,7 \\
Opiskelu & 65 & 17,2 \\
Taloudellinen tilanne & 65 & 17,2 \\
Asiakkuudesta irtautuminen & 36 & 9,5 \\
Terveys & 20 & 5,3 \\
Asuminen & 16 & 4,2 \\
Eläke & 14 & 3,7 \\
Asiakkuuden jatkuminen & 7 & 1,9 \\
Jokin muu & 35 & 9,3 \\
\hline Yhteensä & 378 & 100,0 \\
\hline
\end{tabular}


mattilaisilta apua elämäntilanteeseensa, tukiverkoston tai taloudellista tukea.

Terveyttä koskeviksi toiveiksi oli luokiteltu fyysiseen ja psyykkiseen terveyteen $(n=15)$ sekä päihde- tai muihin riippuvuuksiin $(n=5)$ liittyvät toiveet. Asumiseen ja eläköitymiseen liittyviä toiveita aineistossa esiintyi varsin vähän.

Aineistossa 35 vastaajaa kuvaili sellaisia seikkoja, jotka eivät asettuneet yksiselitteisesti edellä kuvailtuihin luokkiin. Osa näistä vastaajista esitti yleisemmin toiveen paremmasta tai helpommasta tulevaisuudesta $(n=6)$, normaalista arkirytmistä, rutiineista ja arjen sujuvuudesta $(n=8)$. Perheeseen tai läheissuhteisiin liittyviä toiveita $(n=5)$ esiintyi varsin vähän. Tulevaisuutta kuvailtiin myös ilman selkeää toivetta tai tavoitetta $(n=12)$ esimerkiksi yksittäisin adjektiivein, kuten "hyvä" tai "helpompi". Lisäksi esitettiin yksittäisiä toiveita esimerkiksi tietynlaisesta oikeuden päätöksestä, harrastuksista tai onnellisuudesta.

\section{Pohdinta}

Tutkimuksen tarkoituksena oli selvittää, miten aikuissosiaalityön asiakkaat suhtautuvat tulevaisuuteensa ja tarkastella taustatietojen sekä asiakkuutta kuvaavien tekijöiden yhteyttä tulevaisuuteen epävarmasti suhtautumiseen. Lisäksi asiakkaiden tulevaisuuden toiveita tarkasteltiin sisällön erittelyn keinoin. Erilaisia aineistoja ja menetelmiä yhdistämällä pyrimme saamaan moniulotteisen kuvan tutkittavasta ilmiöstä.

Tarkasteltaessa miten aikuissosiaalityön asiakkaat suhtautuvat tulevaisuuteensa havaitsimme, että vastaajista liki kaksi kolmesta suhtautui tulevaisuuteensa luottavaisesti reilun kolmanneksen kokiessa epävarmuutta tulevaisuutensa suhteen. Tulevaisuuteen suhtautuminen oli ristiintaulukoinnissa yhteydessä vastaajan sukupuoleen, ikään, työtilanteeseen ja työttömyyden kestoon. Naiset suhtautuivat tulevaisuuteensa miehiä useammin luottavaisesti, kuten myös alle 30-vuotiaat verrattuna vanhempiin vastaajiin. Työssäkäyvillä, eläkeläisillä ja opiskelijoilla tulevaisuuteen luottavaisesti suhtautuminen oli muunlaisessa elämäntilanteessa olevia vastaajia yleisempää. Myös alle vuoden kestänyt työttömyys oli yhteydessä tulevaisuuteen luottavaisesti suhtautumiseen. Tarkasteltaessa asiakkuuteen liittyviä tekijöitä havaittiin, että alle vuoden kestänyt asiakkuuden kesto, palvelun vastaaminen asiakkaan odotuksia, elämäntilanteen muuttuminen positiivisemmaksi asiakkuuden myötä, hyvä asiakkaan ja työntekijän välinen vuorovaikutus sekä työskentelyn tavoitteellinen luonne olivat yhteydessä tulevaisuuteen luottavaisesti suhtautumiseen.

Selvittääksemme tarkemmin riskitekijöitä, jotka ovat yhteydessä epävarmaan tulevaisuuteen suhtautumiseen jatkoimme analyysiä logistisen regressioanalyysin keinoin. Keskeisiksi riskitekijöiksi osoittautuivat miessukupuoli, palveluodotusten täyttymättömyys sekä työskentelyn tavoitteellisuuden alhainen taso. Miehillä riski suhtautua tulevaisuuteensa epävarmasti oli lähes kolminkertainen naisiin verrattuna. Palveluodotusten täyttymisellä oli suuri merkitys tulevaisuuteen suhtautumiseen. Mikäli palvelu vastasi huonosti odotuksia, riski tulevaisuuteen epävarmasti suhtautumiseen oli kuusinkertai- 
nen verrattuna niihin, joiden odotuksiin palvelu oli vastannut hyvin. Myös työskentelyn tavoitteellisuuden laskiessa riski asiakkaan epävarmuuden kokemukselle liki kaksinkertaistui.

Tutkimuksessa selvitimme myös sisällön erittelyn keinoin mitä aikuissosiaalityön asiakkaat toivovat tulevaisuudeltaan. Tulevaisuuden toiveet liittyivät vahvasti elämän perustarpeiden tyydyttämiseen. Työ osoittautui yleisimmäksi tulevaisuuden toiveeksi. Toiveita kohdistui myös opintoihin, taloudelliseen tilanteeseen, terveyteen, asumiseen ja eläköitymiseen. Lisäksi esitettiin toiveita asiakkuudesta irtautumisesta ja vähemmässä määrin sen jatkumisesta.

Aikuissosiaalityöhön ja sen asiakkaiden tulevaisuuteen kohdistuva tutkimus on ollut varsin vähäistä. Laajemmin väestöön ja eri ikäluokkiin kohdistuvissa tutkimuksissa tulevaisuuteen optimistisesti suhtautuminen on ollut vallitsevaa (Myllyniemi 2017, 36; Pulkkinen \& Polet 2010, 85; Pulkkinen ym. 2003, 84). Käsillä olevassa tutkimuksessa tulevaisuuteen luottavaisesti suhtautuminen ei ollut yhtä yleistä. Kaikkiaan sosiaalityön asiakkaiden suhtautuminen tulevaisuuteensa lienee erilaista kuin väestössä kokonaisuutena; elämää voi leimata monenlainen niukkuus (ks. Kivipelto \& Saikkonen 2018). Sosiaalityön asiakkuuden ei välttämättä ajatella kuuluvan normatiiviseen elämänkaareen. Elämäntilanteeseen voidaan kohdistaa odotuksia, jotka ovat vastakkaisia sosiaalitoimen asiakkuuteen nähden. Sosiaalitoimen asiakkuus saattaakin tuottaa kokemuksia epäonnistumisesta. Tämä voi osaltaan heijastua vastaajien suhtautumiseen tulevaisuuteen ja näkyä myös toiveissa asiakkuuden päättymi- sestä. Halussa irtautua asiakkuudesta voi yhtäältä olla kyse niukkuudesta eroon pääsemisestä ja paremman elämäntilanteen tavoittelusta, mutta toisaalta taustalla voivat olla asiakkuuteen mahdollisesti liittyvät häpeän kokemukset (ks. Blomberg ym. 2016).

Sen lisäksi, että tutkimus tuotti tietoa aikuissosiaalityön asiakkaiden luottamuksesta tulevaisuuteen yleisellä tasolla, tutkimus kohdisti katseen kolmeen keskeiseen seikkaan. Tuloksissa korostuivat sukupuolten väliset erot tulevaisuuteen suhtautumisessa, työllisyyden keskeinen merkitys tulevaisuutta koskevissa odotuksissa sekä sosiaalityön mahdollisuudet tukea aikuissosiaalityön asiakkaita.

Miesvastaajat suhtautuivat käsillä olevassa tutkimuksessa tulevaisuuteensa naisia harvemmin luottavaisesti. Lisäksi riski kokea epävarmuutta tulevaisuutensa suhteen oli heillä selvästi naisvastaajia suurempi. Eri tutkimuksissa on saatu vaihtelevia tuloksia sukupuolen merkityksestä. Suomalaisten aikuisten elämäntyytyväisyyttä koskevassa seurantatutkimuksessa merkittävää eroa eri sukupuolten välillä ei ilmennyt (Pulkkinen ym. 2003, 84; Pulkkinen \& Polet 2010, 85). Tutkimuksessa ikääntyvien elämänkulusta sen sijaan ilmeni miesten epävarmempi tulevaisuuteen suhtautuminen, joka näytti edelleen lisääntyvän hieman iän myötä (Kärnä 2008, 188). On syytä pohtia, miksi aikuissosiaalityön kontekstissa sukupuolten välillä on eroa tulevaisuuteen suhtautumisessa. Herää kysymys, tulevatko miesasiakkaiden tarpeet riittävästi kohdatuksi (ks. Kuronen 2004; Kuronen ym. 2004; Seligson 2008). Tämä haastaa sosiaalityön käytäntöjä. Sosiaalityössä tarvitaankin 
sekä sukupuolierot ymmärtävää että sukupuolisensitiivistä työotetta. Tarkempi sukupuolen mukainen tarkastelu aikuissosiaalityön kontekstissa asettuu tärkeäksi jatkotutkimusaiheeksi.

Työllä ja työelämään kiinnittymisellä on monella tapaa keskeinen rooli aikuissosiaalityön asiakkaiden tulevaisuudessa. Tarkasteltaessa vastaajien työtilannetta työssäkäyvillä, eläkeläisillä ja opiskelijoilla tulevaisuuteen luottavaisesti suhtautuminen oli muunlaisessa elämäntilanteessa olevia vastaajia yleisempää. Opiskelijoilla koulutus saattaa merkitä lupausta paremmasta tulevaisuudesta, jolloin aikuissosiaalityön asiakkuus asettuu väliaikaiseksi elämänvaiheeksi. Aikuissosiaalityön kontekstissa myös eläköityminen, olipa sitten kyse työkyvyttömyys- tai vanhuuseläkkeestä, voi olla elämäntilannetta vakauttava tekijä (ks. Isola ym. 2016, 154-155). Työttömyyden, heikon taloudellisen tilanteen ja terveydellisten huolten on aiemmassa tutkimuksessa todettu olevan yhteydessä toivottomuuteen (ks. Haatainen 2004, 55-60). Myös käsillä olevassa tutkimuksessa yli vuoden työttömänä olleilla tulevaisuuteen epävarmasti suhtautuminen oli yleisempää kuin alle vuoden työttömänä olleilla vastaajilla. Aikuissosiaalityössä tähän voidaan pyrkiä vastaamaan esimerkiksi aktivointisuunnitelman toteuttamisella asiakkaan ja työvoimaviranomaisten kanssa. Aktivointitoimenpiteiden, kuten kuntouttavan työtoiminnan, tuloksena voi kuitenkin olla myös tavoitteen mahdottomuuden toteaminen sekä katseen kohdistaminen työelämän ulkopuolisiin seikkoihin (Elonen ym. 2017).

Vastaajien esittämien tulevaisuuden toiveiden tarkastelu vahvistaa osal- taan edellä kuvailtuja tuloksia; työhön ja opintoihin sekä taloudellisen tilanteen paranemiseen kohdistuvat toiveet osoittautuivat yleisimmiksi. Tutkimuksessa esiin tulleet tulevaisuuden toiveet myötäilevät pääosin aiemmassa aikuissosiaalityön kehittämistyössä esiin nostettuja asiakastyöskentelylle asetettuja tavoitteita (ks. Blomgren \& Kivipelto 2012; Kivipelto ym. 2013; Saikkonen ym. 2015). Tulokset kuitenkin haastavat mielikuvaa moniongelmaisista aikuissosiaalityön asiakkaista. Esimerkiksi elämänhallintaan, asumiseen ja riippuvuuksista toipumiseen liittyviä toiveita esiintyi verrattain vähän siihen nähden, että valtakunnallisessa aikuissosiaalityön kartoituksessa sosiaalityöntekijöistä ja sosiaaliohjaajista yli puolet on kuvaillut käsittelevänsä työssään usein näihin liittyviä seikkoja (Blomgren \& Kivipelto 2012, 73). Vastaajien painottuminen kirjallisesti asioiviin voi osittain selittää tätä tulosta. On myös mahdollista, että erityisen haastavissa elämäntilanteissa elävät asiakkaat eivät välttämättä ole vastanneet kyselyyn.

Havaitsimme sosiaalitoimen asiakkuuteen liittyvien tekijöiden olevan yhteydessä siihen, millaisena tulevaisuus näyttäytyy. Nämä tekijät osoittautuivat sekä käsillä olevassa että aiemmassa tutkimuksessamme (Kuusisto \& Ekqvist 2016) yhteenkietoutuneiksi. Sosiaalitoimen asiakkuuden pitkittyminen voi indikoida moninaisia ja mahdollisesti pitkäkestoisia haasteita asiakkaan elämäntilanteessa. Asiakastyössä haasteena on sekä panostaminen asiakkuuden alkuvaiheeseen tuen tarpeen pitkittymisen ehkäisemiseksi että pidempään asioineiden asiakkaiden todellinen kohtaaminen. Asiakkaan ja palvelujärjestelmän kohtaamattomuus onkin 
noussut esiin laadullisin menetelmin toteutetuissa sosiaalityön tutkimuksissa (mm. Metteri 2012). Asiakaslähtöisellä työskentelytavalla voidaan vahvistaa köyhyydessä elävän selviytymiskeinoja (ks. Isola ym. 2016). Tavoitteellinen työskentely vaatii työntekijältä halua perehtyä asiakkaan tilanteeseen, kuunnella asiakasta ja antaa arvoa asiakkaan mielipiteille (ks. Juhila 2006, 103-149).

Kansallisessa aikuissosiaalityön kartoituksessa tärkeimmiksi aikuissosiaalityön menetelmiksi nostetaan asiakkaan kannustaminen ja voimavarojen etsintä sekä asiakkaan kuunteleminen ja empatian osoittaminen. Näissä korostuvat asiakkaan ja työntekijän välinen vuorovaikutus. Tavoitteellisuus näkyy vahvasti aikuissosiaalityölle keskeisissä menetelmissä, kuten palveluohjauksessa tai etuuksista tiedottamisessa, kriisitilanteessa työskentelyssä, asiakkaan taloustilanteen käsittelyssä sekä työllisyys- ja koulutusasioissa avustamisessa. (Blomgren \& Kivipelto 2012, 40.) Yhteinen ymmärrys avuntarpeesta, asiakkaan saama palveluohjaus ja tiedon välittäminen asiakkaan asian etenemisestä ovat tärkeitä tavoitteelliselle ja tulevaisuuden toivoa luovalle työotteelle. Asiakkaat hyötyvät konkreettisista toimista elämäntilanteen parantamiseksi ja paremman tulevaisuuden tavoittamiseksi.

Tutkimuksella on joitakin rajoituksia. Tutkimuksen tulokset ovat pikemminkin kuvailevia kuin yleistettävissä olevia kadon ja ajallisesti varsin lyhyen aineistonkeruun vuoksi. Demografisten tietojen osalta osallistujat vastasivat kuitenkin hyvin valtakunnallista kuvaa toimeentulotuen saajista (Toimeentulotuki 2014, 2-3). Asiakastyytyväisyyskyselyä toimitettiin sekä työntekijöille asiakkailleen tapaamistilanteessa jaettavaksi että toimeentulotukipäätöksen yhteydessä. Sähköisellä vastausmahdollisuudella pyrittiin nostamaan ennalta alhaiseksi arvioitua vastausprosenttia. Asiakastapaamisilla tapahtunutta aineistonkeruuta ei kontrolloitu, joskin työntekijät ohjeistettiin kyselyn jakamiseen. Työntekijöiden suhtautuminen ja panostaminen aineiston keruuseen voi vaihdella työntekijöittäin. Asiakkaan vastaustapaan on voinut vaikuttaa se, onko asiakas vastannut kyselyyn tavatessaan työntekijää, heti saamansa palvelun jälkeen vai onko tapaamisen ja vastaamisen välillä kulunut pidempi aika. (Hokkanen 2012, 118-121, 131132.) Kyselyn jakaminen toimeentulotukipäätöksen yhteydessä on voinut osaltaan vaikuttaa vastaushalukkuuteen, esimerkiksi kielteinen toimeentulotukipäätös voi lamaannuttaa toisen asiakkaan ja toisaalta taas aktivoida toisessa vastaajassa halun palautteen antamiseen. Tulevaisuuden toiveiden tarkastelun osalta huomionarvoista on, että avovastauksissa tulevaisuuden toiveita kuvaili vain osa vastaajista $(n=204)$.Vastaamatta jättämiseen voi olla monia syitä.Vastaaja ei ehkä ole halunnut kertoa toiveistaan, niiden kuvaileminen kirjallisesti on haasteellista tai kyselyn loppupuolella olevaan kysymykseen ei enää jaksettu vastata.

Asiakastyytyväisyyskyselyn tuloksia tulkittaessa on hyvä huomioida myös asiakkaiden riippuvuus saadusta palvelusta (Hokkanen 2012, 146). Terveydenhuollossa on tullut esiin potilaiden taipumus antaa palvelusta positiivinen arvio huonoista kokemuksista huolimatta. Tietynlainen lojaalius palveluntarjoajia kohtaan sekä alisteinen asema työntekijöihin nähden voi estää nega- 
tiivisen palautteen antamisen. Työntekijöihin halutaan myös säilyttää hyvä suhde, jottei palvelun laatu heikkene tulevaisuudessa. (Ks. Edwards ym. 2004, 167.) Kvantitatiivinen, anonyyminä kerättävä kyselyaineisto ei sisältänyt tähän mainittavaa riskiä. Näitä seikkoja on kuitenkin syytä pohtia arvioitaessa tutkimuksen tuloksia. Hanketyöntekijät ohjeistivat henkilökuntaa niin asiakastapaamisella tapahtuvasta kuin myös kirjalliseen päätökseen liitettävästä aineistonkeruusta. Kyselyn saaneille asiakkaille painotettiin saatekirjeessä, että vastauksia käsitellään luottamuksellisesti eivätkä ne vaikuta toimeentulotuen käsittelyyn. Kyselyyn myös vastattiin nimettömästi.

Tutkimuksen sisällöllisenä rajoitteena on se, että tulevaisuuteen suhtautumista tarkasteltiin vain kaksiluokkaisen muuttujan avulla. Annetut vastausvaihtoehdot asettavat vastakkain tulevaisuuteen suhtautumisen luottavaisin mielin sekä tulevaisuuden tuntumisen epävarmalta. Pohjimmiltaan näemme vastausvaihtoehtojen kuitenkin tuovan esiin tulevaisuuteen suhtautumisen kahtiajaon: tulevaisuuteen voidaan suhtautua pääosin luottavaisesti tai epävarmasti. Tämä tulee esiin myös tulevaisuuden toiveita tarkasteltaessa. Pieni osa vastaajista on ilmaissut vastauksessaan, ettei heillä ole tulevaisuuden toiveita tai tulevaisuus näyttää toivottomalta. Sosiaalityön keskeiseksi tehtäväksi asettuukin luottamuksen lisääminen parempaan tulevaisuuteen haastavissakin elämäntilanteissa (Hepworth ym. 2010, 34-36; Koehn \& Cutcliffe 2012; Rantasalmi 2008, 23).

Tutkimus nostaa esiin työntekijän ja asiakkaan välisen vuorovaikutuksen, tavoitteellisen työskentelysuhteen sekä palveluodotuksiin vastaamisen merkityksen sosiaalityön käytäntöjen kannalta. Tutkimuksessa selvitettiin niitä tekijöitä, jotka lisäävät tai heikentävät luottavaista suhtautumista tulevaisuuteen aikuissosiaalityön asiakkailla. Tulokset voivat parhaimmillaan olla aikuissosiaalityön kehittämisen välineitä nostaessaan esiin niitä toimintatapoja, jotka tukevat asiakkaan luottamusta tulevaisuuteen sekä tavoitteiden saavuttamista. Asiakaslähtöinen työskentelytapa mahdollistaa myös asiakkaan omien toiveiden ja tarpeiden esiin tuomisen työskentelyn keskiöön. Tutkimuksemme perusteella voidaan todeta, että on tärkeää kiinnittää katse saavutettuihin onnistumisiin, mutta myös asiakkaiden kokemuksiin niistä tilanteista, joissa palvelu ei olekaan vastannut odotuksia tai vuorovaikutus työntekijän kanssa ei ole ollut toivotun kaltaista. Jatkotutkimuksen kohteeksi asettuu sen selvittäminen, kuinka tavoitteellinen työote on toteutunut aikuissosiaalityössä taloudellisen ja psykososiaalisen tuen kytköksen muututtua toimeentulotuen Kela-siirron myötä. Merkityksellistä on, kuinka hyvin palvelujärjestelmä kykenee palveluodotuksiin ja asetettuihin tavoitteisiin vastaamaan ja keille tukea kohdennetaan (ks. Julkunen 2006, 167). Aikuissosiaalityössä tarvitaan keinoja ja resursseja edistää asiakkaiden paremman tulevaisuuden tavoittelua yhdenvertaisesti, mutta yksilölliset tarpeet tunnistaen.

\section{VIITE}

1 Työskentelyn tavoitteellisuus ja kokemus vuorovaikutuksesta ovat summamuuttujia, joten vastaajajoukko on näillä muuttujilla 
pienempi. Kyselyssä ohjattiin vastaamaan kyseisiin kysymyksiin vain, mikäli vastaaja on ollut yhteydessä työntekijöihin sosiaalitoimistossa asioidessaan.

\section{KirJallisuUs}

Aapola-Kari, Sinikka \& Wrede-Jäntti, Matilda (2017) Perinteisiä toiveita, nykyhetkeen kiinnittyviä pelkoja - nuoret pohtivat tulevaisuutta. Teoksessa Sami Myllyniemi (toim.) Katse tulevaisuudessa. Nuorisobarometri 2016. Helsinki: Opetus- ja kulttuuriministeriö,Valtion nuorisoneuvosto \& Nuorisotutkimusverkosto, 159-175.

Barnett, Michael D. (2014) Future orientation and health among older adults. The Importance of hope. Educational Gerontology 40 (10), 745-755. https://doi.org/1 $0.1080 / 03601277.2014 .898496$

Bell, Wendell (2003/1997) Foundations of futures studies. Human science for a new era history, purposes, knowledge.Volume 1. Piscataway, New Jersey: Transaction Publishers.

Blomberg, Helena \& Kallio, Johanna \& Kroll, Christian (2016) Häpeää ja laiskuutta. Asiakkaiden, muiden kansalaisten sekä katutason työntekijäryhmien käsitykset toimeentulotukiasiakkuudesta. Yhteiskuntapolitiikka 81 (3), 301-312.

Blomgren, Sanna \& Kivipelto, Minna (2012) Valtaistus - valtakunnallinen aikuissosiaalityön kartoitus. Raportti 27. Helsinki: Terveyden ja hyvinvoinnin laitos.

Chin, Jacqueline \& Holden, Ronald R. (2013) Multidimensional future time perspective as moderators of the relationships between suicide motivation, preparation, and its predictors. Suicide and Life-Threatening Behavior 43 (4), 395-405. https:// doi.org/10.1111/sltb.12025

Dietrich, Julia \& Shulman, Shmuel \& Nurmi, Jan-Erik (2013) Goal pursuit in young adulthood: The role of personality and motivation in goal appraisal trajectories across 6 years. Journal of Research in Personality 47 (6), 728-737. https://doi. org/10.1016/j.jrp.2013.06.004

Edwards, Carol \& Staniszweska, Sophie \& Crichton Nicola (2004) Investigation of the ways which patients' reports of their satisfaction with healthcare are construct- ed. Sociology of Health \& Illness 26 (2), 159-183. https://doi.org/10.1111/j.14679566.2004.00385.x

Elonen, Noora \& Niemelä, Jukka \& Saloniemi, Antti (2017) Aktivointi ja pitkäaikaistyöttömien monenlainen toimijuus. Janus 25 (4), 280-296.

Greene, Jennifer C. \& Sommerfeld, Peter \& Haight, Wendy L. (2010) Mixing methods in social work research. Teoksessa Ian Shaw \& Katharine Briar-Lawson \& Joan Orme \& Roy Ruckdeschel (toim.) The Sage Handbook of social work research. Thousand Oaks CA: Sage, 315-331. https://doi. org/10.4135/9780857021106.n20

Haatainen, Kaisa (2004) Hopelessness in a general population of Finnish adults. Kuopio University Publications D. Medical Sciences 336. Kuopio: Kuopion yliopisto.

Hepworth, Dean H. \& Rooney, Ronald H. \& Dewberry Rooney, Glenda \& StromGottfried, Kimberly \& Larsen, Jo Ann (2010) Direct social work practice: theory and skills. 8. painos. Belmont:Brooks/Cole, Cengage Learning.

Hirsch, Jameson K. \& Duberstein, Paul R. \& Conner, Kenneth R. \& Heisel, Marnin J. \& Beckman, Anthony \& Franus, Nathan \& Conwell, Yeates (2006) Future orientation and suicide ideation and attempts in depressed adults ages 50 and over.The American Journal of Geriatric Psychiatry 14 (9), 752-757. https://doi.org/10.1097/01. JGP.0000209219.06017.62

Hokkanen, Liisa (2012) Sosiaalitoimistojen asiakastyytyväisyyskyselyn tulkinta. Teoksessa Anneli Pohjola \& Tarja Kemppainen \& Sanna Väyrynen (toim.) Sosiaalityön vaikuttavuus. Rovaniemi: Lapin yliopistokustannus, 116-161.

Isola, Anna-Maria \& Turunen, Elina \& Hiilamo, Heikki (2016) Miten köyhät selviytyvät Suomessa? Yhteiskuntapolitiikka 81 (2), 150-160.

Jokinen, Arja (2014) Onnistumisen tarinoita aikuissosiaalityössä. Teoksessa Riitta Haverinen \& Marjo Kuronen \& Tarja Pösö (toim.) Sosiaalihuollon tila ja tulevaisuus. Tampere:Vastapaino, 196-218.

Jokinen, Eeva (2005) Aikuisten arki. Helsinki: Gaudeamus.

Jokivuori, Pertti \& Hietala, Risto (2007) Määrällisiä tarinoita. Monimuuttujamenetelmien käyttö ja tulkinta. Helsinki:WSOY. 
Juhila, Kirsi (2006) Sosiaalityöntekijöinä ja asiakkaina. Sosiaalityön yhteiskunnalliset tehtävät ja paikat. Tampere:Vastapaino.

Juhila, Kirsi (2008) Aikuisten parissa tehtävän aikuissosiaalityön areenat. Teoksessa Arja Jokinen \& Kirsi Juhila (toim.) Sosiaalityö aikuisten parissa. Tampere: Vastapaino, 14-47.

Juhila, Kirsi (2009) Sosiaalityön selontekovelvollisuus. Janus 17 (4), 296-312.

Julkunen, Raija (2006) Kuka vastaa? Hyvinvointivaltion rajat ja julkinen vastuu. Helsinki: Stakes.

Kela (2017) Perustoimeentulotuen siirto Kelaan. Kelan sisäinen arviointi 2017. http://www.kela.fi/documents/10180/3571044/toturaportti0806. pdf/06f4fd6b-50de-4302-b6ea-ac5c2adb0ae9. Luettu 17.10.2018.

Kemppainen, Tarja \& Kostamo-Pääkkö, Kaisa \& Niskala, Asta \& Ojaniemi, Pekka \& Vesterinen, Kerttu (2010) Sosiaalityön vaikuttavuuden arvioinnin ensiaskeleet Lapissa. Tutkimus sosiaalitoimistojen työn vaikuttavuudesta. Rovaniemi: Pohjois-Suomen sosiaalialan osaamiskeskus.

Kivipelto, Minna \& Blomgren, Sanna \& Suojanen, Riitta (2013) AVAIN-mittarin kehittäminen Seinäjoen sosiaalivirastossa. Teoksessa Minna Kivipelto \& Sanna Blomgren \& Pekka Karjalainen \& Paula Saikkonen (toim.) Vaikuttavaa aikuissosiaalityötä - arviointimalleista mittareihin. Tutkimus- ja kehittämishankkeen loppuraportti. Raportteja 8. Helsinki:Terveyden ja hyvinvoinnin laitos, 28-52.

Kivipelto, Minna \& Saikkonen, Paula (2018) Hyvinvointia niukkuudesta? Kokemuksia viimesijaisesta turvasta. Janus 26 (1), 57-72. https://doi.org/10.30668/janus.65291

Kjørstad, Monica (2005) Between professional ethics and bureaucratic rationality: the challenging ethical position of social workers who are faced with implementing a workfare policy. European Journal of Social Work 8(4), 381-398. https://doi. org/10.1080/13691450500314459

Koehn, Corinne V. \& Cutcliffe, John R. (2012) The Inspiration of hope in substance abuse counseling. Journal of Humanistic Counseling 51 (1), 78-98. https://doi. org/10.1002/j.2161-1939.2012.00007.x

Kuronen, Marjo (2004) Valtaistumista vai voimavaraistumista - Feministisia näkökulmia empowermentiin sosiaalityön käsitteenä ja käytäntönä. Teoksessa Marjo Kuronen \& Riitta Granfelt \& Leo Nyqvist \& Päivi Petrelius (toim.) Sukupuoli ja sosiaalityö. Jyväskylä: PS-kustannus, 277-296.

Kuronen, Marjo \& Granfelt, Riitta \& Nyqvist, Leo \& Petrelius, Päivi (2004) Sukupuolistunut ja sukupuoleton sosiaalityö. Teoksessa Marjo Kuronen \& Riitta Granfelt \& Leo Nyqvist \& Päivi Petrelius (toim.) Sukupuoli ja sosiaalityö. Jyväskylä: PS-kustannus, 5-18.

Kuusikko-työryhmä \& Borg, Pekka (2011) Kuuden suurimman kaupungin aikuissosiaalityö 2011. Helsinki: Kuusikko-työryhmä.

Kuusisto, Katja \& Ekqvist, Eeva (2016) Aikuissosiaalityön asiakkaiden kokemus asiakkuuden vaikutuksesta elämäntilanteen muutokseen. Yhteiskuntapolitiikka 81 (6), 655-669.

Kärnä, Sirpa (2008) Hyvinvoinnin pysyvyyttä ja muutosta kolmannessa iässä. Ikääntyvien henkilöiden elämänkulun seuranta vuosina 1991 ja 2004 Varkauden kaupungissa. Kuopion yliopiston julkaisuja E. Yhteiskuntatieteet 166. Kuopio: Kuopion yliopisto.

Metteri, Anna: Hyvinvointivaltion lupaukset, kohtuuttomat tapaukset ja sosiaalityö (2012) Teoksessa Katja Forssén \& Irene Roivainen \& Satu Ylinen \& Jari Heinonen (toim.) Kohtaako sosiaalityö köyhyyden? Sosiaalityön tutkimuksen vuosikirja 2011. Kuopio: UNIpress.

Myllyniemi, Sami (2017) Tilasto-osio. Teoksessa Sami Myllyniemi (toim.) Katse tulevaisuudessa. Nuorisobarometri 2016. Helsinki: Opetus- ja kulttuuriministeriö \& Valtion nuorisoneuvosto \& Nuorisotutkimusverkosto, 9-101.

Mäkinen, Päivi (2014) Muuttuva toimeentulotuki 2014. 371 tapaa tehdä toimeentulotukityötä. Helsinki: Sosiaalialan korkeakoulutettujen ammattijärjestö Talentia ry.

Nummela, Tuija (2011) Asiakkaan asema ja oikeuksien toteutuminen aikuissosiaalityössä. Publications of the University of Eastern Finland, Dissertations in Social Sciences and Business Studies 17. Kuopio: Kuopion yliopisto.

Nurmi, Jan-Erik \& Salmela-Aro, Katariina (2002) Goal construction, reconstruction and depressive symptoms in a lifespan context: the transition from school 
to work. Journal of Personality 70 (3), 385-420. https://doi.org/10.1111/14676494.05009

Pulkkinen, Lea \& Fyrstén, Sanna \& Kinnunen, Ulla \& Kinnunen, Marja-Liisa \& Pitkänen, Tuuli \& Kokko, Katja (2003) 40 +: erään ikäluokan selviytymistarina. Jyväskylän yliopiston psykologian laitoksen julkaisuja 349. Jyväskylä: Jyväskylän yliopisto.

Pulkkinen, Lea \& Polet, Juho (2010) Tyydytystä ja huolta aiheuttavat asiat elämässä. Teoksessa Lea Pulkkinen \& Katja Kokko (toim.) Keski-ikä elämänvaiheena. Jyväskylän yliopiston psykologian laitoksen julkaisuja 352. Jyväskylä: Jyväskylän yliopisto, 75-90.

Rantasalmi, Soile (2008) Aikuissosiaalityön suunnitelmallisuus - kehittämistyön suuntaviivoja. Teoksessa Kari Huotari \& Johanna Hurtig (toim.) Sosiaalityötä monitoroimassa. Helsinki: Palmenia Helsinki University Press, 13-24.

Rita, Hannu \& Töttö, Pertti \& Alastalo, Marja (2008) Voiko turkulaisten kirjoittamista artikkeleista yli $100 \%$ olla kvantitatiivisia? Vetosuhteen (odds ratio) ja vedon (odds) tulkintaa. Janus 16 (1), 72-80.

Rostila, Ilmari (2001) Tavoitelähtöinen sosiaalityö. Voimavarakeskeisen ongelmanratkaisun perusteet. Jyväskylä: Jyväskylän yliopisto SoPhi.

Rubin, Anita \& Linturi, Hannu (2001) Transition in the making. The images of the future in education and decision-making. Futures 33 (3-4), 267-305. https://doi. org/10.1016/S0016-3287(00)00071-9

Saikkonen, Paula \& Blomgren, Sanna \& Karjalainen, Pekka \& Kivipelto, Minna (2015) Poistaako sosiaalityö huono-osaisuutta? Helsinki: Kunnallisalan kehittämissäätiö.
Seligson,Anna (2008) Sosiaaliala ja sukupuoli. Sosiaalialan kehittämishankkeen sukupuolinäkökulman valtavirtaistaminen. Sosiaalija terveysministeriön selvityksiä 2007:70. Helsinki: Sosiaali- ja terveysministeriö.

Shulman, Shmuel \& Barr, Tamuz \& Livneh, Yaara \& Nurmi,Jan-Erik \& Vasalampi, Kati \& Pratt, Michael (2015) Career pursuit pathways among emerging adult men and women: Psychosocial correlates and precursors. International Journal of Behavioral Development 39 (1), 9-19. https://doi. org/10.1177/0165025414533222

STM (2015) Toimeentulotuen uudistamista selvittäneen työryhmän loppuraportti. Helsinki: Sosiaali- ja terveysministeriö.

Toimeentulotuki 2014: Tilastoraportti 27/2015. Helsinki: Terveyden ja hyvinvoinnin laitos.

Tuomi, Jouni \& Sarajärvi, Anneli (2009) Laadullinen tutkimus ja sisällönanalyysi. 5. painos. Helsinki:Tammi.

Webster, Jeffrey Dean \& Ma, Xiaodong (2013) A balanced time perspective in Adulthood: well-being and developmental effects. Canadian Journal on Aging 32 (4), 433-442. https://doi.org/10.1017/ S0714980813000500

Webster, Jeffrey Dean (2011) A new measure of time perspective: Initial psychometric findings for the Balanced Time Perspective Scale (BTPS). Canadian Journal of Behavioural Science 43 (2), 111-118. https://doi. org/10.1037/a0022801 